Rune Andreassen

Førsteamanuensis ved Avdeling for loererutdanning, Høgskolen i Østfold

\title{
Samarbeidslæring - en god måte å utvikle elevenes leseforståelse på? En forskningsoversikt
}

\begin{abstract}
Sammendrag
Artikkelen har som formål å formidle og drøfte forskningsresultater om samarbeidsloering fra de siste 20 årene. På grunnlag av seks metaanalyser blir det vist til effektberegninger og analyser av faktorer som kan påvirke effekten av samarbeidslcering på leseforståelse hos barn i grunnskolealder. Det blir også vist til resultater fra kvalitative studier av elevers erfaringer med samarbeidsloering. Resultatene blir drøftet i forhold til teori om elevsamarbeid og i forhold til ulike former for validitet.
\end{abstract}

\section{Innledning}

I skolens søken etter å realisere det overordende prinsippet om tilpasset opplæring, er samarbeidslæring blitt foreslått som et viktig anliggende (Jensen, 2007). Samarbeidslæring er ikke nevnt direkte i det norske læreplanverket, men i den generelle delen heter det at det skal legges opp til et læringsmiljø der det er rom for samarbeid, dialog og meningsbryting. (Utdanningsdirektoratet, 2006: 3). Studier tyder på at det er lite systematisk bruk av samarbeidslæring, både på barnetrinnet (van Daal, Solheim, Gabrielsen \& Begnum, 2008) og på ungdomstrinnet (Klette \& Lie, 2006). Klette (2008: 13) mener at skolen i liten grad nyttegjør seg "den læringsressursen som ligger i en kollektiv språklig refleksjon" og at faglig samarbeid mellom elevene er lite utbredt selv om elevene ofte sitter sammen i grupper. Fra amerikanske studier (Rosenshine \& Meister, 1994) og egen forskning (Andreassen, 2008) er det indikasjoner på at samarbeid på lesegrupper etter mønster fra Resiprok undervisning (Palincsar \& Brown, 1994) er uvant og vanskelig for lærerne å implementere i klasserommet.

Med dette som bakteppe er formålet med denne artikkelen å gi en oversikt over hva nyere forskning forteller om samarbeidslæring som metode i leseopplæringen. Forskningsbasert kunnskap er viktig når vi skal besvare spørsmålet om dette er noe vi bør satse på i skolen og i lærerutdanningen.

Etter at begrepet samarbeidslæring blir definert og avgrenset, presenterer jeg forskningsresultater i tre hovedavsnitt: 1) Effektforskning, som er kvantitativ forskning som prøver ut samarbeidslæring i forhold til andre måter å organisere læringsaktiviteten på, 2) Faktoranalyse, som forsøker å identifisere bestemte faktorer som innvirker på effekten av samarbeidslæring, og 3) Elevundersøkelser, som er kvalitative studier som forsøker å avdekke elevers egne 
erfaringer med hvordan samarbeidslæring virker. Med noen unntak, for eksempel Torlaug Løkensgard Hoel og Olga Dysthes Vygotsky-inspirerte forskning om samarbeid i responsgrupper (Hoel, 2001 Dysthe, 2001), har samarbeidslæring vært lite forsket på i Norge og Norden forøvrig. Det vil alltid være et spørsmål om ytre validitet og generaliserbarhet når resultater fra for eksempel amerikansk skole skal overføres til en norsk kontekst. Dette er forhold jeg kommer tilbake til i siste del av artikkelen, der resultatene fra 1, 2 og 3 blir diskutert.

For å kunne sammenligne effekter på tvers av studier gjør jeg følgende avgrensninger: 1) målet for samarbeidslæringen skal være leseferdighet, fortrinnsvis leseforståelse, og 2) elevene skal aldersmessig tilsvare norske grunnskoleelever. Da leseforståelse i mindre grad er studert på begynnertrinnene, er de fleste studiene det refereres til foretatt på mellom- og ungdomstrinnet.

\section{Hva er samarbeidslæring?}

I engelskspråklig litteratur brukes forskjellige ord for å betegne samarbeidslæring. De to mest brukte betegnelsene er collaborative learning (ca 115.000 treff på frasen "collaborative learning" i Google scholar) og cooperative learning (ca 82.000 treff på frasen "cooperative learning" i Google scholar). Murphy \& Alexander (2006) skiller mellom de to på følgende måter. Cooperative learning betyr at undervisningssituasjonen tilrettelegges slik at elevene arbeider sammen på en liten gruppe mot et felles mål. I motsetning til konkurransepreget eller individuell undervisningsorganisering, er hver enkelt elevs faglige suksess avhengig av at gruppemedlemmene samarbeider. Johnson og Johnsons (1994) metode "Learning Together and Alone" og Aronsons (1994) puslespillmetode nevnes som eksempler på cooperative learning. Collaborative learning har ifølge Murphy og Alexander som mål å skape enighet eller felles forståelse blant gruppemedlemmene i forhold til et bestemt spørsmål eller tema. "Resiprok undervisning" (Palincsar \& Brown, 1984) og "Scripted Cooperation" (O’Donnell, 2006) er eksempler på dette. O'Donnell (2006) bruker betegnelsen Peer learning som samlebegrep for alle typer samarbeidslæring. Murphy \& Alexander (2006) bruker shared learning som fellesbetegnelse. På lignende måte bruker Lou, Abrami, Spence, Poulsen, Chambers og d'Apollonia (1996) betegnelsen within-class grouping.

I denne artikkelen lar jeg begrepet samarbeidslæring bety samarbeid i en liten elevgruppe (som oftest inntil 5) om et felles mål, for eksempel forståelse av en tekst, der måloppnåelsen fremmes av at alle deltakerne bidrar. Det inkluderer begge de to tilnærmingene til Murphy og Alexander (2006). For at samarbeidslæring skal være et alternativ til lærerstyrt klasseundervisning, må gruppa kunne fungere uten lærer som gruppeleder. Lærerens rolle blir å planlegge, veilede etter behov, og eventuelt sørge for debriefing i form av en oppsummerende læresamtale. I noen former for gruppesamtale er lærerens rolle å være samtaleleder i 
gruppa, og han får dermed en dominerende stilling ved å være den som stiller de riktige spørsmålene. Slik ser det ut til å være for Questioning the Author (Bech, McKeown, Hamilton, \& Kucan, 1997), som er en form for strukturert tekstsamtale, og som er utprøvd i Sverige av Monica Reichenberg (2008). Fordi slike former for samarbeidslæring vanskelig kan gjennomføres i vanlige klasser (med én lærer på 25-30 elever) vil jeg holde slike opplegg utenfor.

De amerikanske forskerpionerene, brødrene David og Roger Johnson, har vært blant de mest produktive på feltet siden 1980-tallet. De har også samarbeidet med og inspirert norske pedagoger, som Ove Kr. Haugaløkken, Aage Aakervik og Egil Hjertaker. Johnson, Johnson, Haugaløkken og Aakervik (1989) skiller mellom tre prinsipielt forskjellige måter samspillet mellom elevene i en læringssituasjon kan organiseres på. I den første måten er læringsarbeidet bygd på konkurranse. Elevene opplever da situasjonen slik at de kan nå sine mål hvis de andre elevene i klassen ikke lykkes i å nå sine mål. Med andre ord lykkes jeg i læringsarbeidet i den grad jeg gjør det bedre enn de andre. Karaktersystemet er trolig med på å opprettholde en slik organiseringsform. Den andre måten er å organisere læringsarbeidet individuelt. Da er det ingen sammenheng mellom egen og andres måloppnåelse. Individualiseringssynspunktet som vokste fram i skolelovgivning og norske undervisningsplaner i siste halvdel av 1900-tallet, kan sees i sammenheng med utstrakt bruk av selvinstruerende og selvkontrollerende materiell (Solerød, 2005). Bruk av individuelle arbeidsplaner, slik vi kjenner det fra norsk skole det siste tiåret, er eksempler på denne organiseringsmåten. For det tredje kan læringsarbeidet organiseres som samarbeid. Dette oppfattes av Johnson et al. (1989) som at elevene arbeider i mindre grupper mot et felles mål. Den enkelte lykkes bare i den grad de andre i gruppa lykkes. Det eksisterer da en positiv gjensidig avhengighet mellom de enkelte gruppemedlemmene. Det er altså positiv sammenheng mellom egen og andres måloppnåelse.

Slavin (1995) gjør rede for to teoretiske begrunnelser for at samarbeidslæring virker læringsfremmende. Den første støtter seg til motivasjonsteorier som fokuserer på hvilke belønningssystemer og mål elevene arbeider under. Etter slike teorier vil felles mål for gruppa og gruppebelønning gitt på grunnlag av summen av den enkeltes fremgang, påvirke gruppemedlemmenes motivasjon til å yte sitt beste og samtidig hjelpe de andre, noe som resulterer i økt læring for alle. Den andre teoretiske begrunnelsen bygger på kognitive teorier som tilsier at det å arbeide sammen gir en effekt i seg selv. Vygotskys (1978) teori om tenkning som internalisering av sosial språklig praksis er sentral her. I denne tilnærmingen har språket en helt sentral rolle i læreprosesser generelt, og i forhold til lesing spesielt. I en samarbeidsgruppe vil elevene få anledning til å observere høyere kognitive prosesser, som lesestrategier og forståelse. I møte med tekst og i dialog med andre konstrueres nye kunnskapsstrukturer. I tråd med Vygotsky kan elever fungere som støtte for hverandre i denne konstruksjonsprosessen. 
Gambrell og Almasis tilnærming til samarbeidslæring som diskusjon På bakgrunn av bl.a. Vygotskys teori utvikler Gambrell og Almasi (1996) begrepet diskusjon for å beskrive sentrale kjennetegn ved samarbeidslæring knyttet til leseforståelse. Almasi (1996) understreker at diskusjon i deres betydning av ordet har et annet innhold enn i den tradisjonelle lærerstyrte tekstsamtalen der læreren har patent på den riktige forståelsen. Den tradisjonelle tekstsamtalen kan sammenlignes med overhøring av elevene. Den preges av såkalte IRE-sekvenser (Cazden, 1988). Det vil si at læreren initierer et spørsmål, en elev gir respons i form av et svar, som så blir evaluert av læreren. Slike kommunikasjonssekvenser ser ut til å ha hatt en dominerende plass i skolen gjennom mange år (Durkin, 1978-1979 og Pressley et al., 1998), og har det antagelig fortsatt i Norge (Anmarkrud, 2009; Klette, 2003).

Gambrell og Almasi (1996) setter fortolkningsprosessen i sentrum istedenfor det rette svaret. Mazzoni \& Gambrell (1996) advarer mot den tradisjonelle tekstsamtalen der læreren forvalter den rette forståelsen. De mener at dette vil kunne føre til passive elever. Elevenes oppgaver blir å reprodusere det rette svaret. I overensstemmelse med nyere leseteori (f.eks. Snow \& Sweet, 2003), betrakter jeg leseforståelse som et samvirke mellom 1) det å trekke ut mening som ligger i teksten og 2) det å konstruere mening fra teksten. Det er det andre aspektet, konstruksjonsprosessen, som er diskusjonens og samarbeidslæringens anliggende.

Rosenshine og Meisters (1994) gjennomgang av 32 studier av Resiprok undervisning, gav dem grunn til å konkludere med at diskusjonen, eller dialogen som er deres ord, er det mest kritiske punktet i samarbeidslæring. Da er det et tankekors at under $5 \%$ av 100 studier av samarbeidslæring foretatt mellom 1980 og 1992 som Meloth og Deering (1999) gjennomgikk, undersøkte gruppediskusjonens innhold.

Gambrell og Almasi (1996) bygger også på Rosenblatts (1938/1976) synspunkt om at forståelse springer ut av transaksjoner mellom leser, tekst og kontekst. Leserens tolkninger er ikke statiske, men blir kontinuerlig utviklet gjennom forhandlinger mellom leserens erfaringer og den nye informasjonen fra teksten. I det sosiale rommet utveksler og utvikler leseren sin tolkning i diskusjon med andre lesere. Tolkninger formes og endres i samhandling med de andre. Med Mazzoni og Gambrells (1996) ord opplever elevene sosiokognitiv konflikt, det vil si en tilstand av kognitiv uro som oppstår når en konfronteres med oppfatninger som er forskjellig fra ens egen. Slike samhandlinger mellom personene i en gruppe blir av Almasi (1996: 3) benevnt som hendelser (events). Mening eller forståelse lokaliseres til hendelsen, ikke til teksten. Kvaliteten på samhandlingen er i denne måten å tenke på bestemt av at gruppemedlemmenes likeverdige deltakelse. Gambrell og Almasis ideelle diskusjonsbegrep bør imidlertid etter min mening problematiseres med for eksempel Cohens statusteori (Cohen, 1994). Elisabeth Cohen bygger på en hypotese om at elever i en gruppe har forskjellig sosial status, og at dette kan forklare systematiske forskjeller når det gjelder gruppemedlemmenes deltakelse i gruppa (Cohen, 1994). 
Statusindikatorer i denne sammenheng er skoleflinkhet og generell popularitet, som hver for seg har sammenheng med hvor aktive og innflytelsesrike elevene er i gruppa. Status defineres som en rangordning det er innbyrdes enighet om. Dermed vil elever med høy status forventes å være mer kompetente både av dem selv og av de andre i gruppa på nær sagt alle områder. Resultatet blir en selvoppfyllende profeti ved av at disse elevene blir mer aktive og generelt mer innflytelsesrike enn de andre. Motsatt statuseffekt blir det for elever med lav status. De vil ofte bli ignorert både når de trenger hjelp og når de kommer med bidrag i gruppa.

\section{Effektforskning}

Ved å oppsummere resultater fra mange forskjellige effektstudier av samarbeidslæring, såkalte metaanalyser, fremkommer det positive læringseffekter, både i matematikk, lesing og andre ferdigheter (Hattie, 2009). I denne artikkelen har jeg kun regnet med studier der minst ett mål for leseforståelse er inkludert som effektvariabel, med elever i alder tilsvarende våre grunnskoleelever.

Tabell 1: Metaanalyser som omtales nærmere i teksten

\begin{tabular}{|l|l|l|l|l|}
\hline Studie & Program & $\begin{array}{l}\text { Antall enkeltstudier } \\
\text { med lesing som } \\
\text { effektvariabel }\end{array}$ & Varighet & $\begin{array}{l}\text { Gj.snittlig effektstørrelse (på } \\
\text { grunnlag av studiene med } \\
\text { lesing) }\end{array}$ \\
\hline $\begin{array}{l}\text { Rosenshine \& Meister } \\
\text { (1994) }\end{array}$ & Resiprocal teaching & 32 (alle) & $\begin{array}{l}6-100 \\
\text { skoletimer. }\end{array}$ & $\begin{array}{l}+0.32 \text { (standardiserte prøver) } \\
+0.88 \text { (forskerprod. prøver) }\end{array}$ \\
\hline $\begin{array}{l}\text { Lou, Abrami, Spence, } \\
\text { Poulsen, Chambers \& } \\
\text { d'Apollonia (1996) }\end{array}$ & $\begin{array}{l}\text { Ulike program for } \\
\text { samarbeidsæring }\end{array}$ & 38 (av totalt 66) & $\begin{array}{l}\text { Minst to } \\
\text { skoletimer } \\
\text { fordelt på to } \\
\text { dager. }\end{array}$ & $\begin{array}{l}+0.13 \text { (mest standardiserte } \\
\text { prøver, men også innslag av } \\
\text { andre) }\end{array}$ \\
\hline Slavin (1995) & $\begin{array}{l}\text { Ulike program for } \\
\text { samarbeidslæring }\end{array}$ & 12 (av totalt 99) & Mer enn 4 uker. & $\begin{array}{l}+0.25 \text { (mest standardiserte } \\
\text { prøver) }\end{array}$ \\
\hline $\begin{array}{l}\text { Rohrbeck, Ginsburg- } \\
\text { Block, Fantuzzo \& } \\
\text { Miller (2003) }\end{array}$ & $\begin{array}{l}\text { Ulike program for } \\
\text { samarbeidsæring }\end{array}$ & 26 (av totalt 90) & Ukjent & +0.26 (ukjente prøver) \\
\hline $\begin{array}{l}\text { Slavin, Cheung, Groff } \\
\text { \& Lake (2008) }\end{array}$ & $\begin{array}{l}\text { Peer-Assisted } \\
\text { Learning, Student } \\
\text { Team Reading, The } \\
\text { Reading Edge }\end{array}$ & 6 (av totalt 33) & 12 uker -1 år & +0.34 (standardiserte prøver) \\
\hline $\begin{array}{l}\text { Dignath, Buettner \& } \\
\text { Langfeldt (2008) }\end{array}$ & Ulike program & 9 (av totalt 48) & $\begin{array}{l}15-60 \\
\text { skoletimer. }\end{array}$ & +0.33 (prøver ikke oppgitt) \\
\hline
\end{tabular}

I Tabell 1 har jeg presentert mitt utvalg av metastudier av samarbeidslæring fra de siste to tiårene der leseferdighet/leseforståelse inngår som effektvariabel. Jeg har ekskludert enkeltstudier der effektvariabelen er noe annet enn leseforståelse når jeg har beregnet gjennomsnittlig effektstørrelse (kolonnen lengst til høyre). Studiene er identifisert ved hjelp av søk i de elektroniske databasene ERIC 
(Education Resources Information Center) og Academic Search Premier. Treff som matcher søkeordene meta analysis kombinert med cooperative, alternativt collaborative learning, er blitt vurdert med tanke på kriteriene ovenfor. Videre har det vært en forutsetning at det er brukt kontrollgruppe og at effektstørrelse (Cohens $d$ ) er oppgitt. Cohens $d$ beregnes som differansen mellom kontrollgruppas og tiltaksgruppas gjennomsnitt (her endringsskåregjennomsnittene), delt på standardavviket for kontrollgruppa eller for begge gruppene til sammen (Vogt, 2005). For å tolke effektstørrelsen har jeg forholdt meg til Cohen (1988) som angir +0.20 som liten, +0.50 som middels og +0.80 som stor effekt. En effektstørrelse på +0.50 betyr en forskjell mellom intervensjons- og kontrollgruppe tilsvarende et halvt standardavvik i favør av intervensjonsguppa. Studieutvalget inneholder en blanding av eksperimentelle og kvasieksperimentelle design.

Allerede på 1980-tallet undersøkte Johnson \& Johnson effekten av samarbeidslæring $\mathrm{i}$ forhold til konkurranse og individuelt arbeid. I sin omfattende metaanalyse av 323 enkeltstudier fant de at resultatene gikk i signifikant favør av samarbeidslæring i mer enn $50 \%$ av studiene. Bare $10 \%$ gikk i favør av individuell læring eller konkurranse. Videre fant de at den positive virkningen av samarbeidslæring var størst når betingelsene om positiv gjensidig avhengighet og individuell ansvarlighet var sikret. De to elementene blir derfor satt som forutsetninger som må ivaretas når det skal tilrettelegges for samarbeidslæring hos Johnson et al. (1989). Robert Slavin (gjengitt i Putnam, 1998) føyer til et tredje element, nemlig like muligheter for den enkelte til å oppleve fremgang og dermed bidra til gruppas fremgang. For å oppnå dette kan den enkeltes fremgang måles ut ifra deres tidligere prestasjoner.

Det er imidlertid store forskjeller mellom studiene som inngår i metaanalysen som er nevnt ovenfor når det gjelder størrelsen på effektene som rapporteres. Noe av dette kan skyldes at de bruker ulike fag og ferdigheter som effektvariabel. Jeg har identifisert seks nyere metaanalyser (Tabell 1) av studier som alle har leseforståelse som mål for elevsamarbeidet. Det er ofte ikke rapportert hvilke tekster det samarbeides om, men hovedsakelig ser det ut til å være fagtekster som er benyttet. De 123 enkeltstudiene som inngår i disse analysene består av ulike program for samarbeidslæring. Den eneste analysen som bare inneholder studier av ett og samme program er Rosenshine og Meister (1994). Dette er en metastudie av Resiprok undervisning (Palincsar \& Brown, 1984), et program for å utvikle leseforståelsen gjennom dialoggrupper, med lesestrategier som et viktig element. I de opprinnelige studiene til Palincsar og Brown var den ene forskeren, og senere elevenes lærere, aktivt med som dialogledere når dette programmet ble evaluert. Etter hvert er det imidlertid blitt prøvd ut i studier uten lærer som dialogleder. Metaanalysen til Rosenshine og Meister (1994) inneholder studier av begge typene. Gjennomsnittlig effektstørrelse på leseforståelse var relativt lav, +0.32 når det ble brukt på standardiserte leseprøver. Ved bruk av forskerproduserte prøver var effekt- 
størrelsen på hele +0.88 . Ingen av disse studiene hadde kontrollgruppe som avvek kun med hensyn til undervisningsorganisering (samarbeidslæring vs individuell/konkurranse). Effektstørrelsen er beregnet på grunnlag av forskjellen på endringsskåren i tiltaksgruppa og endringsskåren i kontrollgruppa, men der kontrollgruppa er av varierende beskaffenhet fra studie til studie. (Slik er det gjennomgående i disse metastudiene.)

Lou et al.(1996) er den av metaanalysene som viser minst effekt av samarbeidslæring. Noe som ikke fremgår av Tabell 1 er at effekten på leseforståelse $(+0.13)$ er enda mindre enn på matematikk $(+0.20)$. I utgangspunktet inkluderte denne metastudien elever fra småskole til videregående, og effektvariabler var ferdigheter på ulike områder. Avgrenset etter mine kriterier, ble jeg stående igjen med 38 av totalt 66 enkeltstudier. En mulig forklaring på at gjennomsnittlig effektstørrelse er så liten i denne studien, kan være at gruppearbeidet ikke er nærmere definert. Kvaliteten på gruppearbeidet er ikke sikret gjennom for eksempel prinsippet om positiv gjensidig avhengighet. Det ser ikke ut som om innholdet i samarbeidet ble definert nærmere som grunnlag for å bli regnet som "within-class grouping". For å bli inkludert i analysen var det tilstrekkelig at intervensjonen besto av minst to undervisningstimer fordelt på to dager. Det er vanskelig å tenke seg at effekter kan fremkomme på grunnlag av en såpass kort intervensjon.

Den neste studien i Tabell 1 er Slavins (1995) store metaanalyse av 99 effektstudier. Slavin krevde at intervensjonene måtte ha en varighet på minst fire uker for å bli tatt med i analysen. Videre var det bare studier som brukte randomisert fordeling av elever på grupper (kontroll- og intervensjonsgruppe) eller matchede grupper som ble inkludert. Jeg har her foretatt et utvalg av enkeltstudier, da det var mange av dem som hadde andre effektvariabler enn leseforståelse eller ikke var i overensstemmelse med mitt alderskriterium. Dermed ble jeg stående med 12 studier, og gjennomsnittlig effektstørrelse for disse var +0.25 , altså en liten, positiv effekt. Noen studier oppgav effektstørrelser for elevgrupper med spesialundervisning, og disse viste gjerne større effekter enn for heterogene grupper. I de fleste av de 12 enkeltstudiene var det samarbeidslæring etter programmet Cooperative Integrated Reading and Composition (CIRC) som ble gjennomført. Som for flere varianter av samarbeidslæring inneholder også CIRC noen andre undervisningselementer i tillegg til samarbeidslæring (slik som en-til-en-veiledning og foreldresamarbeid). Det gjør det vanskelig å si noe om hvor mye av effekten som skyldes selve tekstsamarbeidet på grupper, og hvor mye som skyldes andre ting.

En nyere metaanalyse av Rohrbeck, Ginsburg-Block, Fantuzzo og Miller (2003) inkluderte 90 enkeltstudier av samarbeidslæring i ulike varianter. Effektvariablene i disse studiene var leseferdighet, inkludert leseforståelse, og matematikkferdighet, fordelt med ca halvparten på hvert område. Når antallet studier er blitt redusert av meg fra 90 til 26 (se Tabell 1) skyldes det at alle studier der matematikk var effektvariabel og der elevene var utenfor grunnskolealder er 
utelatt. I de aller fleste studiene var gruppene homogene i alder, men heterogene i forhold til evner. Totalt for alle studiene fant de en gjennomsnittlig effektstørrelse +0.33 . Effektstørrelsen for de 26 studiene som oppfylte mine kriterier var +0.26 . Program og varighet på intervensjonene kan ikke leses direkte ut av rapporten. Det som er mest interessant med denne metaanalysen er at de også så på hvilke faktorer som bidro til effekt. Jeg vil derfor komme tilbake til denne studien.

De to siste metaanalysene i Tabell 1 består ikke utelukkende av studier som omhandler samarbeidslæring, men de inneholder henholdsvis sju og ni studier av samarbeidslæring knyttet til lesing. Det er disse jeg konsentrerer meg om. Slavin, Cheung, Groff \& Lakes (2008) metaanalyse inneholder ulike leseprogram som ble studert med tanke på effekter på blant annet leseforståelse. Én av de sju studiene av samarbeidslæring er foretatt på high school-nivå. Denne ser jeg bort fra i den videre behandlingen. For å bli inkludert i metaanalysen måtte studien bruke randomiserte eller matchede grupper (intervensjon vs kontroll). Tre forskjellige program for samarbeidslæring ligger til grunn for de seks studiene: Fuchs, Fuchs, Mathes \& Simmons' (1997) Peer-Assisted Learning Strategies (PALS), Stevens og Durkins (1992) Student Team Reading og Slavin, Daniels og Maddens (2005) The Reading Edge. Cirka 9500 elever deltok i disse studiene. To av studiene brukte randomiserte design, fire hadde matchede grupper. På standardiserte leseprøver (flere forskjellige) er det en gjennomsnittlig effektstørrelse på +0.34 på disse seks studiene. Effektstørrelsen varierer imidlertid mye mellom studiene, fra $+0.12(p<.05)$ til $+0.66(p<.05)$. For spesialundervisningselever fant man større effekt enn for gjennomsnittseleven, nemlig +0.60 .

Den siste studien i Tabell 1, Dignath, Buettner og Langfeldt (2008), er en metaanalyse av 48 effektstudier av treningsprogram i selvregulert læring. Et ukjent antall av studiene som inngikk i analysen inneholdt gruppearbeid med et felles læringsmål. Programmene var for øvrig ulike i det at de trente elevenes selvregulering $\mathrm{i}$ forskjellige fag og emner, der lesing var ett av dem. Ni av studiene inneholdt til sammen 20 effektvariabler for leseferdighet/leseforståelse. Forfatterne er selv overrasket over at effektstørrelsen var signifikant høyere i de studiene som ikke brukte gruppearbeid sammenlignet med der det var fellesundervisning eller individuelt arbeid, $\mathrm{d}=+0.53 \mathrm{vs} \mathrm{d}=+0.33$, når leseprøver var effektvariabel. Selv om det var en positiv effekt av gruppearbeid i forhold til kontrollgruppene, var effekten av selvregulert læring større uten bruk av samarbeidslæring. Det var sparsomt med implementeringsdata tilgjengelig og lite informasjon om elevenes tidligere erfaringer med gruppearbeid i de studiene som inngikk i analysen. Det er derfor vanskelig å vite hvordan gruppearbeidet ble gjennomført og hvordan det virket. Mangelen på implementeringsdata er en stor svakhet ved mange pedagogiske effektstudier, og er en trussel både mot begrepsvaliditet og ytre validitet (muligheten for å kunne generalisere). Som en mulig forklaring på den negative effekten av gruppearbeid, nevner forfatterne at 
elevene ikke var vant til gruppearbeid og ikke mottok nok undervisning om samarbeidslæring.

Uten vekting er gjennomsnittlig effektstørrelse for de tellende studiene som inngår i Tabell $1+0.35$ dersom både standardiserte og forskerproduserte tester er inkludert i den første studien, og +0.28 dersom de forskerproduserte testene er utelatt her. Det vil si en liten til middels effekt, med andre ord at elevene som brukte samarbeidslæring gikk fram omtrent et tredjedels standardavvik mer enn det kontrollgruppene gjorde. Til sammenligning har John Hattie (2009) i sine omfattende metaanalyser funnet at cooperative learning har en effektstørrelse på lesing og matematikk på +0.41 i forhold til uspesifiserte kontrollgrupper. Fire av de 10 studiene som inngår i hans analysegrunnlag er upubliserte, fire av dem er fra 1990 eller tidligere. Ingen av de 10 inngår i mitt analysegrunnlag (Tabell 1).

\section{Faktoranalyser}

Forskning om samarbeidslæring ser ut til å ha beveget seg fra å undersøke generelle tendenser eller effekter av denne måten å organisere læringsarbeidet på til å være opptatt av hvorfor det virker noen ganger og ikke andre ganger, og under hvilke betingelser samarbeidslæring virker (Slavin, 1996). Det kan gjøres ved å sammenligne alternative former for samarbeidslæring eller ved å kartlegge tredjefaktorer som kan virke inn på effekten. Det kan være implementeringsvariabler eller prosessvariabler (hva og hvordan det ble gjennomført), demografiske variabler (egenskaper ved elevutvalget) eller kontekstuelle variabler (under hvilke betingelser programmet virket). Faktoranalyse brukes altså her ikke kun om en statistisk metode, men mer generelt om å undersøke faktorer som kan ha betydning for effekten. Noen av metastudiene som inngår i Tabell 1 gjør en nærmere analyse av slike faktorer. Forhold ved teksten, som sjanger og tema, er sjelden gjenstand for analyse.

La oss først se litt nærmere på studien til Rosenshine og Meister (1994). Her påpekes det at det er få opplysninger fra de enkelte studiene som gir grunnlag for å vurdere kvaliteter ved dialogen slik den ble gjennomført på gruppene. Bortsett fra tre studier, var det lite transkripsjoner tilgjengelig fra gruppedialogene for nærmere analyse. Av de få elevfaktorer som kunne identifiseres, går det fram at det ikke var signifikant forskjell på effekten hos sterke og svake elever (når det gjelder leseforståelse). Det var heller ingen signifikante utslag når det gjaldt klassetrinn eller gruppestørrelse. Mest oppsiktsvekkende er det kanskje at det ikke var forskjell i effekt etter hvor lenge intervensjonen varte. Denne studien gir oss derfor lite hjelp til å identifisere faktorer av betydning.

I studien gjort av Lou et al. (1996) ble også effekten analysert på grunnlag av gruppestørrelsen, i tillegg til gruppesammensetning, om gruppene var faste eller skiftende, om det var positiv gjensidig avhengighet mellom gruppedeltakerne (for eksempel bruk av gruppebelønning) og om det ble brukt tilpasset undervisningsmateriale (for den enkelte gruppe). Den optimale gruppestørrelsen så ut 
til å være $3-4$ elever. Det at læreren setter sammen gruppene så ut til å påvirke effekten positivt, og det var en generell tendens til at homogene grupper ( $\mathrm{i}$ forhold til evner/ferdigheter) var positivt sammenlignet med heterogene grupper. For svake elever var imidlertid heterogene grupper å foretrekke, mens middels sterke profiterte på homogene grupper. For sterke elever så ikke gruppens sammensetning ut til å bety noe særlig. Hvorvidt gruppene var faste eller ble endret underveis, så ikke ut til å innvirke på effekten. Det var derimot av betydning om elevene var positivt gjensidig avhengige av hverandre, slik det er definert i cooperativ learning (Johnson \& Johnson, 1989). Undervisningsmateriell (tekster) som var tilpasset den enkelte gruppe var naturlig nok av betydning.

Mengden trening lærerne fikk før implementeringen var forøvrig relatert til effekten. Det så ut til at lengre og mer intensiv trening for lærerne gav bedre implementering og dermed større utbytte for elevene. Likeledes så det ut til at effekten hadde positiv sammenheng med at gruppearbeidet ble kombinert med eksplisitt undervisning, for eksempel instruksjon i samarbeidslæring. Det vi kan konkludere med etter denne studien, er at det neppe gir positive effekter i seg selv bare å sette elevene i grupper. Det er måten vi gjør det på og hvordan vi legger opp gruppearbeidet og dialogen som avgjør.

Dette er også en av konklusjonene Slavin (1995) trekker av sin analyse. Enkeltstudier der det var definert et felles mål for gruppa kombinert med individuell ansvarlighet, gav best effekt $(\mathrm{d}=0.32)$ sammenlignet med studier som bare hadde én av de to betingelsene eller ingen av dem oppfylt. Slavins (1995) studie finner for øvrig ikke klare indikasjoner på at det er bestemte elevkategorier, for eksempel svake elever, som profiterer mer enn andre.

Gjennom sin metaanalyse av 90 intervensjonsstudier der samarbeidslæring ble prøvd ut i skolens seks første trinn (fra 6 år), identifiserte Rohrbeck et al. (2003) en rekke demografiske karakteristika og intervensjonsparametere som vil kunne påvirke effekten av samarbeidslæring. Graden av struktur er én av disse parameterne, som ifølge teori (se tidligere beskrivelse) vil kunne ha betydning. I Rohrbeck et al.'s studie var imidlertid strukturert samarbeidslæring ikke signifikant mer effektivt enn ustrukturert. Strukturert var her definert som det å la elevene bli støttet av roller i sin interaksjon med hverandre. Andre forhold som ble undersøkt var elevkontroll versus lærerstyring. Det viste seg at intervensjoner med høy grad av elevkontroll var mer effektive enn de som var mer lærerkontrollerte. Indikatorer for elevkontroll var det å være med å bestemme målet, styre og vurdere gjennomføringen og velge belønning. Gruppebasert belønning viste seg for øvrig mer effektivt enn individuell belønning, noe som er i overensstemmelse med Johnson \& Johnsons prinsipp om positiv gjensidig avhengighet. Det er verdt å merke seg at studiene som var inkludert i analysen alle hadde faglig læring som mål, omtrent like mange var rettet mot lesing som mot matematikk. I faktoranalysene blir det ikke skilt mellom de to. 
Selv om Rohrbeck og medarbeideres metaanalyse viste en gjennomsnittlig positiv effektstørrelse på +0.33 totalt $(+0.26$ for lesing), varierte effektene på enkeltstudiene mellom $-0.61 \mathrm{og}+1.50$. Dette indikerer at gruppearbeid ikke automatisk gir positive resultater, men faktisk også kan ha negative følger for læring. Hogan og Tudge (1999) mener forskning har gått fra en generell tro på at all sosial interaksjon nødvendigvis fører til kognitiv vekst - til en økende oppmerksomhet på sammensetningen av faktorer som kan tjene til å fremme eller hindre utvikling, eller endog føre til negativ utvikling.

De to siste metastudiene i Tabell 1 mangler dessverre data som kan danne grunnlag for å identifisere kritiske faktorer i samarbeidslæring. Dermed kan vi foreløping konkludere med at effektstudier er best på å fortelle om et program har en effekt slik det er blitt gjennomført og noe om hvor stor effekten er. Slike studier i mindre grad egnet til å si noe om årsakene til effekten eller manglende effekt.

\section{Kvalitative studier av hvordan og hvorfor samarbeidslæring virker}

I jakten på årsaker har noen forskere gått inn i klasserommet for å observere og/eller spørre elevene om deres erfaringer med samarbeidslæring i samband med utvikling av leseforståelse. I dette avsnittet vil jeg først se på to intervjustudier. I den ene spurte man elever på høyere trinn (fra åttende klasse $\mathrm{i}$ amerikansk skole), i den andre elever på 3.-5. trinn. Jeg vil deretter referere kort fra en observasjonsstudie med filmopptak fra gruppesamtalene, der selve tekstsamtalen i elevgruppene ble studert. Studiene er funnet ved å gjennomgå referansene i de studiene som inngår i den kvantitative analysen (Se Tabell 1).

Alvermann et al.s studie (1996) av elever på høyere trinn, er den første av de to intervjustudiene. Her ble det gjort videoopptak av samarbeidssekvenser i fem klasserom, som så dannet utgangspunkt for strukturerte fokusgruppeintervjuer med elevene etterpå. To forskjellige samarbeidssettinger ble filmet: lærerstyrte helklasse-samtaler og elevstyrte gruppesamtaler. Det var snakk om klasser som brukte slike arbeidsmåter regelmessig. Det var ingen intervensjon i den forstand at lærerne ble bedt om å legge om sin undervisning. Hensikten med studien var å undersøke elevenes erfaringer med og meninger om tekstrelaterte samtaler i klasserommet. På grunnlag av film- og intervjudata, fremholder forskerne tre hovedfunn som kjennetegnet elevenes tanker om samarbeidslæring. For det første: Elevene var bevisste på bestemte betingelser som bidro til god samtale/diskusjon. Fire betingelser trekkes fram: 1) De aller fleste foretrakk gruppediskusjoner framfor klassediskusjoner. Dette ble begrunnet på flere måter: De slapp å vente lenge på å få ordet, det opplevdes hyggeligere ved at folk lyttet til hverandre, det var lettere å ta ordet, og det var mer akseptert å være usikker eller si noe som var feil. Elever som foretrakk klassesamtaler så i hovedsak ut til å være ungdommer fra kulturelle minoriteter som følte at de ble holdt utenfor $\mathrm{i}$ gruppa. 2) Elevene foretrakk å arbeide i grupper der de kjente hverandre og likte 
hverandre. Likevel ønsket mange at læreren skulle bestemme hvem de skulle være på gruppe sammen med. 3) Elevene mente at alle hadde ansvar for å bidra på gruppa. 4) De mente det var viktig å være fokusert på oppgaven eller temaet $\mathrm{i}$ teksten de skulle diskutere for at gruppearbeidet skulle gi resultater.

Det andre hovedfunnet om elevenes oppfatninger av samarbeidslæring var at oppgaven loereren presenterte og tema som teksten handlet om, innvirket på deltakelsen i diskusjonen. Elevene definerte diskusjonsvennlige oppgaver som at de var interessante og diskuterbare (kontroversielle). Opplysninger om tema og teksttype er i liten grad gjort rede for.

Det tredje hovedfunnet var at elevene betraktet diskusjonen som en hjelp til å forstå det de leste. Dette begrunnet de med at de lyttet til hverandre, satte ord på tankene sine og argumenterte for synspunktene sine, og at de utviklet ordforrådet sitt. De brukte mye tid til å snakke om betydningen av å oppklare vanskelige ord.

Ifølge forskerne indikerer resultatene at gruppediskusjoner engasjerer elevene og bidrar til å konstruere mening. Når samarbeidslæring er en del av klasses ordinære plan, slik det var i disse klassene, lærer elevene å arbeide sammen, å opprettholde fokus på tema, og de lærer betydningen av å lytte og bidra til gruppas beste. Studien indikerer at gruppediskusjoner fungerer best når kontroll og myndighet overføres til elevene, og at det elevene kommer fram til etter å ha diskutert en tekst vil kunne være noe annet enn det læreren har tenkt seg.

Den andre studien er gjort i forhold til yngre elever. I Elbaum, Moody og Schumms (1999) todelte studie ble først vel 500 tredje-, fjerde- og femteklassinger spurt om deres erfaringer med ulike typer gruppearbeid i leseundervisningen ved å la dem fylle ut et spørreskjema. Det viste seg at heterogene smågrupper (evnemessig) og toergrupper (par) var det de fleste foretrakk, mens homogene grupper og individuelt arbeid var minst populært. Studien ble fulgt opp med en interessant intervjuundersøkelse av 55 av tredjeklassingene, inkludert 27 med lærevansker der de ble bedt om å begrunne sine preferanser. Noen kategorier av forklaringer utkrystalliserte seg. Når det gjaldt kategorien arbeidsbetingelser mente mange av elevene, enten de hadde lærevansker eller ikke, at det ble mye støy i klasserommet, og at noen elever forstyrret når de arbeidet på grupper. I tillegg mente mange at det var vanskeligere å få hjelp av læreren når de hadde gruppearbeid. Det ble ofte lenge å vente. Dette tyder på at gruppearbeidet i liten grad fungerte som samarbeidslæring, slik jeg definerte det tidligere i artikkelen. Elever med lærevansker var bekymret for at medelever skulle ha det moro på deres bekostning (make fun of them), og noen hadde opplevd å bli gjort narr av på grunn av lesevanskene sine. For noen var klasseundervisning å foretrekke fordi de kunne la være å rekke opp hånda når de ikke visste svaret, og på den måten gjemme seg bort og skjule sin uvitenhet. Flere elever, både med og uten lærevansker, opplevde engstelse når de ble satt $\mathrm{i}$ grupper med flinkere elever. Generelt likte sterke elever å hjelpe sine klassekamerater. Noen opplevde imidlertid heterogene smågrupper som frustrerende 
fordi svake elever hindret dem i å komme videre. Det er viktig å ta elevenes bekymring alvorlig, og resultatene ovenfor bør det tas hensyn til når forutsetninger for produktivt samarbeidslæring diskuteres. En læringssituasjon der elevene er utrygge og engstelige fremmer ikke læring. Derfor vil trygghet og forventning om mestring være en forutsetning for at samarbeidslæring skal gi gode resultater også faglig. En kritikk mot Elbaum, Moody og Schumms studie er at elevenes oppfatninger ikke ser ut til å være koblet til hvilken form for gruppearbeid det refereres til. Vi vet derfor ikke i hvilken grad og på hvilken måte det var samarbeidslæring det var snakk om her.

Den tredje studien med bruk av kvalitative forskningsmetoder er Klingner, Vaughn og Schumms (1998) utprøvingsstudie av programmet Collaborative Strategic Reading i et lite utvalg amerikanske fjerdeklasser. Tekstene som ble benyttet var samfunnsfagstekster (historie). Ved å analysere filmopptak av elevstyrte gruppesamtaler fant de at åpne og elaborerte diskusjoner ikke er en automatisk følge av å la elevene arbeide sammen om tekstrelaterte oppgaver. Tvert imot observerte Klingner et al. at elevene sjelden gav uttrykk for uenighet med hverandre om innholdet $\mathrm{i}$ tekstene. Istedenfor å fremme diskusjon basert på ulike meninger, så forskerne at fjerdeklasseelever som var gruppeledere initierte IREsekvenser, slik de antakelig hadde observert læreren gjøre det. Det vil si at de stilte spørsmål, forventet et svar, og vurderte om svaret var riktig. Dette understreker at det kan være nødvendig å arbeide målrettet over tid for at elevene skal tilegne seg nye diskursferdigheter som forutsettes i produktiv samarbeidslæring. Trolig er det en sammenheng mellom lærerens og elevenes måte å lede dialogen på.

\section{Sammenfatning og diskusjon}

Her vil jeg kort sammenfatte det som er fremkommet gjennom de tre typene av analyser jeg har referert til og drøfte denne kunnskapen i forhold til teorien jeg presenterte i første del av artikkelen. Jeg vil også drøfte usikkerhetsmomenter vi står overfor når vi skal trekke slutninger av forskningen omkring samarbeidslæring.

\section{Hovedtendens fra effektstudiene.}

Tendensen er at samarbeidslæring gir en effekt på læringsutbyttet i form av økt leseforståelse/leseferdighet. Effekten er imidlertid liten til moderat, og er avhengig av mange forhold som har sammenheng med hvordan samarbeidslæringen blir gjennomført og forhold som ligger utenfor metoden. Gjennom faktoranalyser har man forsøkt å identifisere slike forhold.

\section{Hovedtendenser fra faktoranalysene.}

Samarbeidslæring kan bety mange forskjellige ting, og gjennomføres på mange ulike måter og $\mathrm{i}$ forhold til et mangfold av elever. Undersøkelsene jeg har 
referert til er dessverre ikke samstemte med hensyn til hvilke faktorer som øker læringseffekten. Naturlig nok er det en tendens til høyere effekt når intervensjonen varer lenger. Videre peker resultatene i retning av at følgende faktorer er av betydning:

a) I den grad det er av betydning, ser det ut til at relativt små grupper (3-4 elever) er å foretrekke.

b) Høy grad av struktur, for eksempel i form av å gi elevene ulike roller i gruppearbeidet, fremmer ikke nødvendigvis effekten av samarbeidslæring, men dette kan variere med alder. Trolig vil yngre elever profitere mer enn eldre på støtte i form av høy grad av struktur.

c) Det ser ut til at elevkontroll med hensyn til å være med å bestemme målet, vurdere gjennomføringen og eventuelt velge belønning er mer effektivt enn om læreren gjør det.

d) Gruppenes sammensetning har betydning, men det ser ut til å ha ulik betydning for ulike typer elever. Særlig er det svake elever (for eksempel elever med lærevansker) som ser ut til å profitere på heterogene grupper (Se også McMaster \& Fuchs, 2002 for en diskusjon om dette).

e) Positiv gjensidig avhengighet mellom gruppedeltakerne er av betydning. Slik avhengighet kan fremmes ved å ansvarliggjøre den enkelte ved at gruppas resultat gjøres avhengig av den enkeltes innsats.

\section{Hovedtendenser fra de kvalitative studiene.}

Noen av de samme tendensene vi så ovenfor går igjen her, men i tillegg gir de kvalitative dataene mer konkret og detaljert informasjon om læringsfremmende faktorer i gruppesamarbeid. Følgende forhold av betydning ble funnet når elevene ble intervjuet eller observert i samarbeidssituasjonen:

a) I overensstemmelse med funn i metaanalysene gir elevene uttrykk for at gruppesammensetningen er av betydning, men på ulik måte for sterke og svake elever. Det ser også ut til å være avhengig av alder/klassetrinn, ved at de eldste (ungdomsskolealder) synes å mene at "like barn leker best".

b) Positiv gjensidig avhengighet blir vektlagt, i hvert fall av de eldste elevene i grunnskolealder.

c) Å være oppgavefokusert blir fremhevet som viktig, men også som en utfordring. Særlig de yngre hadde negative opplevelser med uro og forstyrrelser fra medelever.

d) Trekk ved oppgaven eller teksten påvirket elevenes engasjement. Fra studien til Alvermann et al. (1996) trekker jeg den slutning at oppgavefokus ble større når det var engasjerende og tankeprovoserende tekster og oppgaver. 
e) En del yngre svake elever og eldre elever med minoritetsbakgrunn forteller at de er utrygge og føler de kommer til kort når de jobber med samarbeidslæring.

f) Yngre elever ser ut til å være mer avhengig av feedback og hjelp fra læreren. Eldre elever ønsker å være mer selvstyrte.

Er disse funnene i overensstemmelse med teorien til Gambrell og Almasi (1996) slik den er gjort rede for i et tidligere avsnitt? En premiss for deres forståelse av samarbeidslæringens virkemåte er at en tilnærmet fri meningsutveksling er mulig. Det vil si at sosiokognitive konflikter kan utspille seg uten at dialogen bryter sammen. Videre at er det et felles ønske om å komme fram til en dypere forståelse, beriket av at alle deltar. En slik interesse av og evne til å identifisere seg med gruppa, vil være avhengig av at ikke statuseffekter dominerer samspillet mellom elevene. Det er flere funn som tilsier at elevene ikke alltid arbeider under betingelsen om fri diskusjon der alle deltar på like fot.

I følge Gambrell og Almasi er det de svake elevene i en heterogen gruppe som vil kunne profitere mest på samarbeidslæring fordi disse elevene vil dra nytte av å ha sterkere elever rundt seg. I følge Hogan og Tudge (1999) er det mange studier, på tvers av fag og læringsinnhold, som bekrefter at elever profiterer å arbeide sammen med en mer kompetent partner. Dette er også $i$ overensstemmelse med Vygotskys teori om hvordan kognitive ferdigheter læres gjennom internalisering av språklige handlinger med mer kompetente andre. Samtidig er det store utfordringer og fare for utrygghet for en del av de faglig svake elevene fordi de vil kunne oppleve at de har lite å bidra med på gruppa, og vil være mer utsatt for negativ oppmerksomhet og negative forventninger. At de svake elevene er spesielt utsatt $\mathrm{i}$ så måte, er i overensstemmelse med Cohens statusteori slik vi kort har gjort rede for den tidligere. Funn som tilsier at yngre og svake elever profiterer på lærerstyring og høy grad av struktur, vil være viktig å ta hensyn til for å forhindre at statuseffekt utvikler seg. Bevisst arbeid med å skape positiv gjensidig avhengighet vil kunne forhindre negative utslag av statuseffekt, fordi den enkelte lykkes som et resultat av at alle gruppemedlemmenes bidrar med sitt.

Det ser ikke ut til at Gambrell og Almasi (1996) tematiserer problemet med statusforskjeller mellom elevene. Den fri og utvungne diskusjonen som de forutsetter vil antakelig være avhengig av at læreren målbevisst bygger opp positiv gjensidig avhengighet og sosiale ferdigheter hos elevene. En slik diskusjon er antagelig også avhengig av en viss motivasjon for å forstå teksten. Funn av Alvermann et al. (1996) viser at teksten og oppgavens beskaffenhet er med på å bestemme hvor sterkt elevenes engasjement vil være. Som vi har sett viser de hvordan engasjerende samtaler eller diskusjoner er mulig å realisere for elever i amerikansk åttende klasse. Det ser videre ut til at Gambrell og Almasis teori om tekstsamarbeid forutsetter et utviklingsperspektiv i forhold til sosiale ferdigheter. Elever trenger åpenbart å trene opp grunnleggende samarbeids- 
ferdigheter tidlig, slik at de etter hvert er i stand til å styre gruppeprosessen og lære gjennom gruppearbeidet uten at læreren er en del av gruppa.

Til slutt vil jeg fremheve noen forhold ved forskningen som vi bør ta hensyn til når det skal trekkes slutninger fra forskning om samarbeidslæring til pedagogisk bruk av samarbeidslæring. Jeg benytter meg av Shadish, Cook og Campbells (2002) fire validitetskategorier for å avdekke usikkerhetsmomenter, eller trusler mot validitet, som forfatterne omtaler det som.

Usikkerhet ved statistisk validitet. For det første er det uklart om effektstørrelsene er beregnet på samme måte i alle studiene som sammenlignes. Dette vil ha konsekvenser for de effektstørrelsene som rapporteres. Selv om det synes å være Cohens $d$ som brukes, er det uvisst hvilke standardavvik som inngår $\mathrm{i}$ utregningen av effektstørrelse. For det andre vil varierende antall deltakere i enkeltstudiene føre til varierende statistisk power og dermed usikkerhet omkring effektstørrelsene. For det tredje er det ikke alltid slik at statistisk signifikans er ensbetydende med pedagogisk signifikans. En effektstørrelse på rundt +0.30 kan karakteriseres som liten til middels. Selv om den er statistisk signifikant, er det et vurderingsspørsmål om dette er stort nok til at metoden bør anbefales, og i tilfelle for hvem. Vi vet at det medfører et betydelig opplæringsbehov og trening før lærere er komfortable med samarbeidslæring (2-3 år ifølge Putnam, 1998). Etter min mening tilsier ikke forskningsresultatene at prinsippet om metodefrihet for læreren bør svekkes.

Usikkerhet ved indre validitet. Dette gjelder usikkerhet ved de slutninger vi trekker om årsak - virkning. Er det samarbeidslæringen i seg selv som gir effekt på leseforståelse, eller kan det tenkes andre faktorer som virker sammen med samarbeidslæring eller som påvirker både samarbeidslæringen og resultatene på leseprøvene? Vi har allerede nevnt ulike programelementer som ofte inngår (for eksempel struktur, systematikk og sosial trening). En kan også tenke seg at faktorer som ikke inngår som en komponent i programmet, som trivsel og klassemiljø, kan øke motivasjonen og dermed også prestasjonene. Mange av studiene er ikke randomiserte eksperiment, slik at gruppene vil være ulike på flere områder før implementeringen starter. Kvasieksperimentelle design krever omfattende statistisk kontroll for såkalte tredjevariabler, noe som ikke alltid er tilfelle i de refererte studiene. Mange av studiene har dessuten ubehandlet kontrollgruppe (det er altså bare intervensjonsgruppa som får økt oppmerksomhet), noe som kan føre til at en (ukjent) del av effekten kommer av økt oppmerksomhet.

Usikkerhet ved begrepsvaliditet. Begrepet på årsakssiden som vi ønsker å studere er samarbeidslæring. Som vi har sett er det et begrep som kan tillegges forskjellig innhold. Studiene gjør ikke alltid rede for begrepsinnholdet, og metaanalyser vil derfor kunne bestå av studier som forstår samarbeidslæring på forskjellig måte. Når samarbeidslæring skal operasjonaliseres foreligger det heller ikke alltid implementeringsdata som kan fortelle om samarbeidslæring er blitt 
gjennomført etter intensjonen. På effektsiden har jeg valgt leseforståelse. Selv om de fleste studiene benytter seg av standardiserte leseprøver, er det forskjellige prøver som er brukt fra studie til studie. Metaanalysene gir ikke alltid opplysninger om hvilke (Se tabell 1). En bestemt prøve vil bare måle ett eller noen aspekter ved det teoretiske begrepet. Dermed vil det være ulike sider ved leseforståelsen som effekten er fremkommet på fra studie til studie, for eksempel overflateforståelse vs dybdeforståelse (Andreassen \& Bråten, in press).

Usikkerhet ved ytre validitet. Metaanalysene det er referert til i denne artikkelen består for det meste av amerikanske studier (fordi USA har den desidert største forskningsaktiviteten også på dette feltet). Selv om de er gjort i autentiske klasserom, som regel med elevenes vanlige lærere, er det usikkerhet knyttet til det å overføre resultatene til norske forhold. De tre kvalitative studiene jeg har vist til har lite antall elever og av den grunn svak generaliseringskraft. Det er også usikkerhet forbundet med å generalisere over tid på grunnlag av fremgang fra pre- til posttest. En slik umiddelbar effekt av et tidsavgrenset tiltak vil ikke automatisk være gyldig på permanent basis. Vi vet heller ikke så mye om hvor intensivt eller hvor gjennomgående samarbeidslæring må brukes for at det skal bli en integrert del av lærernes og elevenes måte å tilnærme seg læringsstoffet på.

\section{Konklusjon}

Til tross for all usikkerhet forbundet med å overføre forskningsresultater til undervisningspraksis, håper jeg artikkelen har gitt et bidrag til å kunne vurdere forutsetningene for produktiv samarbeidslæring i skolen. Det gjelder særlig forhold ved gruppesammensetning, utvikling av positiv gjensidig avhengighet, og å finne en god balanse og progresjon i forholdet mellom lærerstyring og elevkontroll. Om samarbeidslæring er en god måte å utvikle leseforståelse på, er antagelig avhengig av om læreren er i stand til å ivareta disse forutsetningene.

Evidensbasert undervisning byr på mange utfordringer. I tillegg til de som er nevnt, vet vi at ulike sosialiseringsverdier varierer, ikke bare mellom mennesker, men også fra kultur til kultur. Verdiene samarbeid og selvstendighet settes ofte opp mot hverandre. Verdien selvstendighet står for eksempel sterkere i kulturer med protestantisk bakgrunn, som den norske, enn i kulturer med katolsk bakgrunn (Fjellvang, in press). Det er ikke utenkelig at det kan påvirke holdningen til samarbeid hos både lærere, foreldre og elever. Det understreker behovet for å prøve ut samarbeidslæring systematisk i norsk skole før det kan anbefales som en god måte å organisere læringsarbeidet på her. Slike intervensjoner bør studeres både kvantitativt, for å finne hovedtendenser, og kvalitativt, for å få kunnskap om hvorfor og hvordan samarbeidslæring virker i norske klasserom. Samarbeidslæring er en måte å forholde seg til andre mennesker på i en læringssituasjon. Slik sett kan det være en motsats til den økende individual- 
iseringen $\mathrm{i}$ skolen, slik den kommer til uttrykk i individuelle arbeids- og læreplaner og i testkulturen. I tillegg til spørsmålet om effekter på læringsutbyttet, må vi også stille det berettigede spørsmålet om hva elevene lærer om læring med de metodene som benyttes.

\section{Litteratur}

Almasi, J.F. (1996). A new view of discussion. I L.B. Gambrell \& J.F. Almasi (red.), Lively Discussions! Fostering engaged reading. (s. 2-24). Newark, Delaware: IRA.

Alvermann, D.E., Young, J.P., Weaver, D., Hinchman, K.A., Moore, D.W., Phelps. S.F., et al. (1996). Middle and high school students' perceptions of how they experience text-based discussions: A multicase study. Reading Research Quarterly, 31, 244-267.

Andreassen, R. (2008). Eksplisitt leseforståelsesundervisning i norske femteklassser: $E t$ felteksperiment. Upublisert doktorgradsavhandling. Stavanger: Det humanistiske fakultet, Universitetet i Stavanger.

Andreassen, R., \& Bråten (in press). Examining the prediction of reading comprehension on different multiple-choice tests. Journal of Research in Reading.

Anmarkrud, Ø. (2009). Undervisning i lesestrategier og utvikling av lesemotivasjon på ungdomstrinnet. Upublisert doktorgradsavhandling. Oslo: Det utdanningsvitenskaplige fakultet, Universitetet i Oslo

Aronson, E. (1994). The social animal. ( $7^{\text {th }}$ ed.) New York: Freeman

Beck, I. L., McKeown, M. G., Hamilton, R. L. \& Kucan, L. (1997). Questioning the Author. An Approach for Engaging Student Engagement with Text. Newark, Delaware: International Reading Association.

Cazden, C.B. (1988). Classroom discourse: The language of teaching and learning. Portsmouth: Heinemann.

Cohen, E.G. (1994). Restructuring the classroom: Conditions for productive small groups. Review of Educational Research, 64, 1-35.

Cohen, J. (1988). Statistical power analysis for the behavioral sciences (2.nd ed.) Hillsdale, NJ: Erlbaum Associates.

Dignath, C., Buettner, G., \& Langfeldt, H.P. (2008). How can primary school students learn self-regulated learning strategies most effectively? A meta-analysis on self-regulation training programmes. Educational Research Review, 3, 101-129.

Durkin, D. (1978-1979). What classroom observation reveals about reading comprehension instruction. Reading Research Quarterly, 14, 481-533.

Dysthe, O. (2001). Mappemetodikk med sosiokulturell forankring. I: O. Dysthe (Red.), Dialog, samspel og loering (s. 333-348). Oslo: Abstrakt forlag.

Elbaum, B., Moody, S.W., \& Schumm, J.S. (1999). Mixed-ability grouping for reading: What students think. Learning disabilities research \& practice, 14, 61-66.

Fjellvang, T. (in press). Socialization values, cultural-religious zones and modernization theory. European Sociological Review.

Fuchs, D., Fuchs, L.S., Mathes, P.G., \& Simmons, D.C. (1997). Peer-assisted learning strategies: Making classrooms more responsive to diversity. American Educational Research Journal, 34, 174-206.

Gambrell, L.B., \& Almasi, J.F. (1996). Lively Discussions! Fostering engaged reading. Newark, Delaware: IRA.

Hattie, J. (2009). Visible learning: A synthesis of over 800 meta-analyses relating to achievement. New York: Routledge. 
Hoel, T.L. (2001). Ord på vandring: Elevar i samtale om tekstar. I: O. Dysthe (Red.), Dialog, samspel og loering (s. 269-288). Oslo: Abstrakt forlag.

Hogan, D. \& Tudge, J.R.H. (1999). Implications of Vygotsky's Theory for Peer Learning. I: A.M.O'Donnell, \& A. King (Eds.), Cognitive perspectives on peer learning (s. 39-65). Mahwah, NJ: Erlbaum.

Jensen, R. (2007). Tilpasset opplaering i en larende skole: Om utvikling av laeringsmiljøet. Stjørdal: Læringsforlaget.

Johnson, D.W., \& Johnson, R.T. (1989). Cooperation and competition: Theory and Research. Edina, MN: Interaction Book Company.

Johnson, D.W., \& Johnson, R.T. (1994). Learning together and alone ( $2^{\text {nd }}$ ed.). Englewood, NJ: Prentice-Hall.

Johnson, D.W., Johnson, R.T., Haugaløkken, O.K., \& Aakervik A.O. (1989). Samarbeid $i$ skolen. Namsos: Pedagogisk psykologisk forlag.

Klette, A. (2003). Lærernes klasseromsarbeid. I: K. Klette (Red.), Klasseromments praksisformer etter Reform 97 (s. 39-76). Oslo: Det utdanningsvitenskapelige fakultet, Universitetet i Oslo.

Klette, A. (2008). Ensidig bruk av arbeidsplaner. Bedre skole 2/2008 (s. 8-13).

Klette, A., \& Lie. S. (2006). Sentrale funn. Foreløpige resultater fra PISA+ studien. URL: www.pfi.uio.no/forskning/forskningsprosjekter/pisa+/index.html [Lastet ned 19.03.2010]

Klingner, J.K., Vaughn, S., \& Schumm, J.S. (1998). Collaborative strategic reading during social studies in heterogeneous forth-grade classrooms. The Elementary School Journal, 99, 3-22.

Lou, Y., Abrami, P., Spence, J., Poulsen, C., Chambers, B., \& d'Apollonia, S. (1996). Withinclass grouping: A meta-analysis. Review of Educational Research, 66, 423-458.

Mazzoni, S.A., \& Gambrell, L.B. (1996). Text talk: Using discussion to promote comprehension of informational texts. I: L.B. Gambrell, L.B., \& Almasi, J.F. Lively Discussions! Fostering engaged reading (s. 134-148). Newark, Delaware: IRA.

McMaster, K.N. \& Fuchs, D. (2002). Effects of cooperative learning on the academic achievement of students with learning disabilities: An update of Tateyama-Sniezek's review. Learning Disabilities Research \& Practice, 17, 107-117.

Meloth, M.S., \& Deering, P.D. (1999). The role of the teacher in promoting cognitive processing during collaborative learning. I: A.M. O’Donnell \& A. King. (Eds.), Cognitive perspectives on peer learning (s. 235-255). Mahwah, NJ: Erlbaum.

Murphy, P.K., \& Alexander, P.A. (2006). Understanding how students learn: A guide for instructional leaders. Thousand Oaks, CA: Corwin Press.

O'Donnell, A.M. (2006). The role of peers and group learning. In P.A. Alexander, \& P.H. Winne (eds.): Handbook of Educational Psychology (2 ${ }^{\text {nd }}$ ed.) (s. 781-802). Mahwah, NJ: Erlbaum.

Palincsar, A.S., \& Brown, A. L. (1984). Reciprocal teaching of comprehension-fostering and comprehension-monitoring activities. Cognition and Instruction, 1, 117-175.

Pressley, M., Wharton-McDonald, R., Mistretta-Hampston, J.M., \& Echevarria, M. (1998). Literacy instruction in ten grade 4/5 classrooms in upstate New York. Scientific Studies of Reading, 2, 159-194.

Putnam, J.W. (1998). The process of cooperative learning. I: J.W. Putnam (Ed.) Cooperative learning and strategies for inclusion: Celebrating diversity in the classroom. (s.17-47). Baltimore, Maryland: Brookes Publ.

Reichenberg, M. (2008). Vägar till läsförståelse: Texten, läsaren och samtalet. Stockholm: Natur \& Kultur. 
Rohrbeck, C.A., Ginsburg-Block, M.D., Fantuzzo, J.W., \& Miller, T.R. (2003). Peer-assisted learning interventions with elementary school students: A meta-analytic review. Journal of Educational Psychology, 95, 240-257.

Rosenblatt, L.M. (1938/1976). The reader, the text, the poem: The transactional theory of the literary work. Carbondale: Southern Illinois University Press.

Rosenshine, B., \& Meister, C. (1994). Reciprocal teaching: A review of the research. Review of Educational Research, 64, 479-530.

Shadish, W.R., Cook, T.D., \& Campbell, D.T. (2002). Experimental and quasi-experimental designs for generalized causal inference. New York: Houghton Mifflin.

Slavin, R.E. (1995). Cooperative learning: Theory, research, and practice. Needham Heights, MA: Allyn \& Bacon.

Slavin, R.E. (1996). Research on cooperative learning and achievement: What we know, what we need to know. Contemporary Educational Psychology, 21, 43-69.

Slavin, R.E., Cheung, A., Groff, C., \& Lake C. (2008). Effective reading programs for middle and high schools: A best-evidence synthesis. Reading Research Quarterly, 43, 290-322.

Slavin, R.E., Daniels, C., \& Maddens, N.A. (2005). "Success for All" middle schools add content to middle grades reform. Middle School Journal, 36, 4-8.

Snow, C.E. \& Sweet, A.P. (2003). Reading for Comprehension. I: Sweet, A.P. \& Snow, C.E. (Eds.) Rethinking Reading Comprehension. New York: Guilford Press.

Solerød, E. (2005). Pedagogiske grunnproblemer - $i$ historisk lys. Oslo: Universitetsforlaget.

Stevens, R.J., \& Durkin, S. (1992, September). Using student team reading and student team writing in middle schools: Two evaluations (Report nr. 36). Baltimore; MD: Johns Hopkins University, Center for research on effective schooling for disadvantaged students.

Utdanningsdirektoratet (2006). Lareplan for Kunnskapsløftet. Midlertidig utgave. Oslo: Utdanningsdirektoratet.

Van Daal, V., Solheim, R.G., Gabrielsen, N.N., \& Begnum, A.C., (2007). PIRLS. Norske elevers leseinnsats og leseferdigheter. Stavanger: Lesesenteret, Universitetet i Stavanger.

Vogt, W.P. (2005). Dictionary of statistics \& methodology: A nontechnical guide for the social sciences $\left(3^{\text {rd }}\right.$ ed.). Thousand Oaks, CA: Sage.

Vygotsky, L.S. (1978). Mind in Society: The development of higher psychological processes. Cambridge, MA: Harvard university press. 